\title{
TRENDS OF CHILDREN'S HEIGHT AND PARENTAL UNEMPLOYMENT: A LARGE-SCALE ANTHROPOMETRIC STUDY ON EASTERN GERMANY, 1994 - 2006
}

\author{
JOERG BATEN \\ ANDREAS BÖHM
}

CESIFO WORKING PAPER NO. 2189

CATEGORY 3: SOCIAL PROTECTION

JANUARY 2008
An electronic version of the paper may be downloaded
- from the SSRN website: Www.SSRN.com
- from the RePEc website: $\quad$ www.RePEc.org
- from the CESifo website: www.CESifo-group.org/wp




\title{
TRENDS OF CHILDREN'S HEIGHT AND PARENTAL UNEMPLOYMENT: A LARGE-SCALE ANTHROPOMETRIC STUDY ON EASTERN GERMANY, 1994 - 2006
}

\begin{abstract}
The average height of children is an indicator for the quality of nutrition and health care. Heights have never declined over longer time spans in Eastern Germany since 1880 - except for the most recent period 1997-2006. In the Eastern German Land of Brandenburg, a data set of 253,050 pre-school height measurements was compiled and complemented with information on parents' schooling and employment status. Unemployment might have negative psychological effects, with impact on health care. Both a panel analysis of districts and an assessment at the individual level yield the result that increasing unemployment was in fact the major driving force.
\end{abstract}

JEL Code: E24, H53, I12, I32.

Keywords: height, unemployment, Eastern Germany, welfare measurement.

\author{
Joerg Baten \\ Department of Economics \\ University of Tuebingen \\ Mohlstrasse 36 \\ 72074 Tuebingen \\ Germany \\ joerg.baten@uni-tuebingen.de
}

\author{
Andreas Böhm \\ Public Health Department Brandenburg \\ Germany \\ andreas.boehm@lga.brandenburg.de
}

We thank Dorothee Crayen, John Komlos, Harald Martenstein, Eva Rosenstock, and seminar participants in Tuebingen and Guidel, and (on a related study) in Strasbourg and UPF Barcelona for important comments. Able research assistance was provided by Rita Benyus, Christian Dick, Nicole Ferstl, Michael Schneider, and many others. Financial help from the ESF GlobalEuroNet Program is thankfully acknowledged. 


\section{Introduction}

The average height of children serves as an indicator for the quality of nutrition and health care (Tanner 1990, Steckel 1997, Komlos 1989, 1996). In the present study, we employ this indicator to assess social development in Eastern Germany, a region afflicted by exorbitant unemployment rates in the past two decades. What we find is that after an initial substantial height increase of school starters in the Eastern German Land of Brandenburg between the reunification of 1990 and 1995, the upward trend stopped suddenly and even developed into a downturn in children's heights between 1997 and 2000. Since 2000, heights have been stagnating at a low level. This is all the more remarkable, as heights have never declined over longer time spans in Eastern German Lands since 1880 - except for the most recent period 1997-2006 (Table 1).

Table 1: Long-run Height Development in Jena (Thueringen) and Brandenburg

\begin{tabular}{lrrr}
\hline Region & Period & Height increase & Height increase per decade \\
\hline Jena & $1880-1921$ & 4.7 & 1.1 \\
Jena & $1921-1932$ & 3.0 & 2.7 \\
Jena & $1932-1944$ & 0.5 & 0.4 \\
Jena & $1944-1954$ & 1.2 & 1.2 \\
Jena & $1954-1964$ & 1.1 & 1.1 \\
Jena & $1964-1975$ & 2.8 & 2.5 \\
& & & \\
Brandenburg & $1987-1997$ & 2.7 & 2.7 \\
Brandenburg & $1997-2006$ & -0.3 & -0.3 \\
\hline Source: Jena: $:$ Jäger et al (1990), Brandenburg:
\end{tabular}

Source: Jena : Jäger et al. (1990), Brandenburg: see text.

At first glance, economic factors might be deemed to have little impact on children's height in an affluent country like Germany. After all, one might assume that even the low income of unemployed parents would suffice for the provision of all basic needs. However, this line of argumentation loses ground in light of the development of Eastern German heights described above. In this study, we therefore argue that height is indeed influenced by unemployment, even in OECD countries like Germany. This has been found in cross- 
sectional studies in other countries as well, such as Britain in the mid-1980s for 10,172 primary-school children (Rona and Chinn 1991). Rona and Chinn controlled for the height of parents, social class, family size and other characteristics, and still found an independent influence of unemployment of $1.2 \mathrm{~cm}$. In our study on Eastern Germany, we can even assess those differences over time, between 1994 and 2006, which provides further insights. Furthermore, we maintain that the study of heights can yield important insights into the social and economic development of Eastern Germany. Our findings are based on a new data set of 253,050 height measurements of children around the age of 6 , which was used for the first time in this study.

Eastern Germany offers itself like few other regions for assessing the impact of unemployment on children's height, since it has long been suffering from drastic unemployment rates. Especially if both parents are unemployed, the quality of nutrition, medical resources and family life could decline in many cases. Thus, frustration and psychological stress might pave the way for reduced care or other compensating behaviour, resulting in parents allowing more unhealthy behaviour than before. In our study, we assess whether the share of parental unemployment in a district has a significant negative influence on the development of heights. Other potential determinants of height (such as health facilties, family structure, and education) fail to explain the development of height over time.

Height differences are important sui generis, as, for example, self-confidence is often influenced by heights. Based on this relationship, economists use height as an indicator for the willingness to accept risks (Dohmen et al. 2006; Goerke and Pannenberg 2007). Robert F. Fogel (1994) stressed in his lecture to the Nobel Prize committee that a height gap of $17.5 \mathrm{~cm}$ meant even for modern Norwegian males in the 1960s and 1970s a higher probability of dying in the following period of not less than 71 percent, clearly a large amount (Figure 1). He based his work on H. Waaler (1984), who measured several thousands of Norwegians and followed them in a longitudinal study. Norway had one of the populations with the best 
nutrition in the late $20^{\text {th }}$ century. Baten and Komlos (1998) estimated that a centimetre of height equals about 1.2 years of life expectancy, with only negligible coefficient change over time between the birth cohorts of 1860, 1900, and 1950, i.e. the latter being adults in the 1970s to the present. Hence, already one centimetre is clearly a meaningful amount, as living 1.2 years more or less is a substantial asset in the quality of life portfolio. For children, the relationship between height and longevity is even closer (Martorell 1985, Billewicz and MacGregor 1982).

Figure 1: Height and mortality risk (Norway 1963-79, males aged 40-59. Source: Fogel (1994)

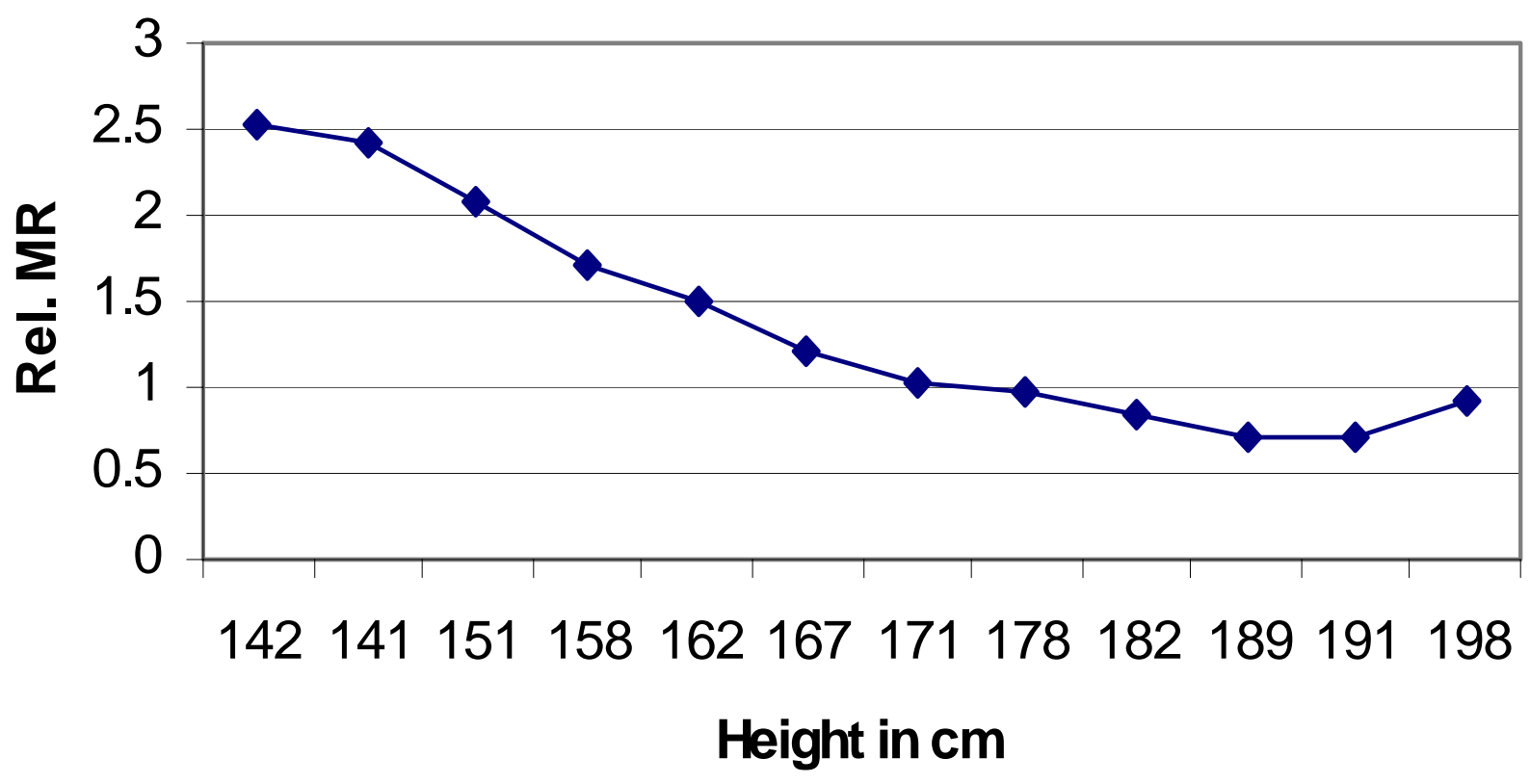

This paper is structured as follows: after a short review of the literature on height determinants, especially in Germany and former socialist countries, the new data set is described along with its strengths and limitations. In the third section, we analyze the effects of regional parental unemployment in a panel of districts and annual observations. Section 4 tests the robustness of our results by adding a number of other variables. Moreover, height 
determinants are analyzed at the individual level. For example, we study whether female education plays a particularly large role in determining children's height. Other determinants could include, the number of siblings, or the number of adults in a household who can provide additional care. However, none of these variables can explain the negative height trend after 1997. Unemployment and its psychological concomitants remains therefore the most plausible explanation of children's height in the Eastern Germany during the 1990s and 2000s.

\section{Literature}

Adult height is influenced by the quality of nutrient intake, disease environment, and the care received by parents and other persons, which leads to optimal resource usage and avoidance of hazards. This effect on adult height is particularly important during the first three years of life, because growth is most pronounced in those years. However, in the case of still-growing children, the environmental determinants of the period preceeding height measurements are also crucially important. This strong influence of the 12 months before measurement has also been confirmed in a study by Baten and Wagner (2003) on the height of school-children in Germany during the first half of the $20^{\text {th }}$ century (Figure $2 \mathrm{a}$ and $2 \mathrm{~b}$ ). Heights declined strongly during WWI and the malnutrition period of 1946-48. In contrast, redistribution programs and medico-hygienic improvements in the Weimar period increased human stature dramatically. Interestingly, during the national socialist period - and even before WWII - heights stagnated. Baten and Wagner (2003) have argued that this was caused by the national socialist anti-trade (and anti-semitic) policies, as well as by the national socialists' striving for autarchy. It were always the twelve months before measurement which had the strongest influence on children's height, as for example the hunger year 1947 led to the lowest height in 1948. This relationship has been amply documented in the anthropological literature. For example, Tanner (1990) describes this as a "target-seeking process": growing individuals adjust their subsequent growth to current circumstances. For example, if in one year the amount of 
healthy nutrients is poor or the disease burden is high, the body waits and does not grow. If the situation stays bad, adult stature is accordingly stunted. If times get better, catch-up growth is possible and adult stunting might be minimal. The advantage of stunting during chronic malnutrition periods is that shorter individuals need to consume less energy, hence survival is more likely. In conclusion, poor nutrition, health environment, or parental care during the months before measurement can lead to lower growth paths of children.

Figure 2a: Heights of children in Stuttgart

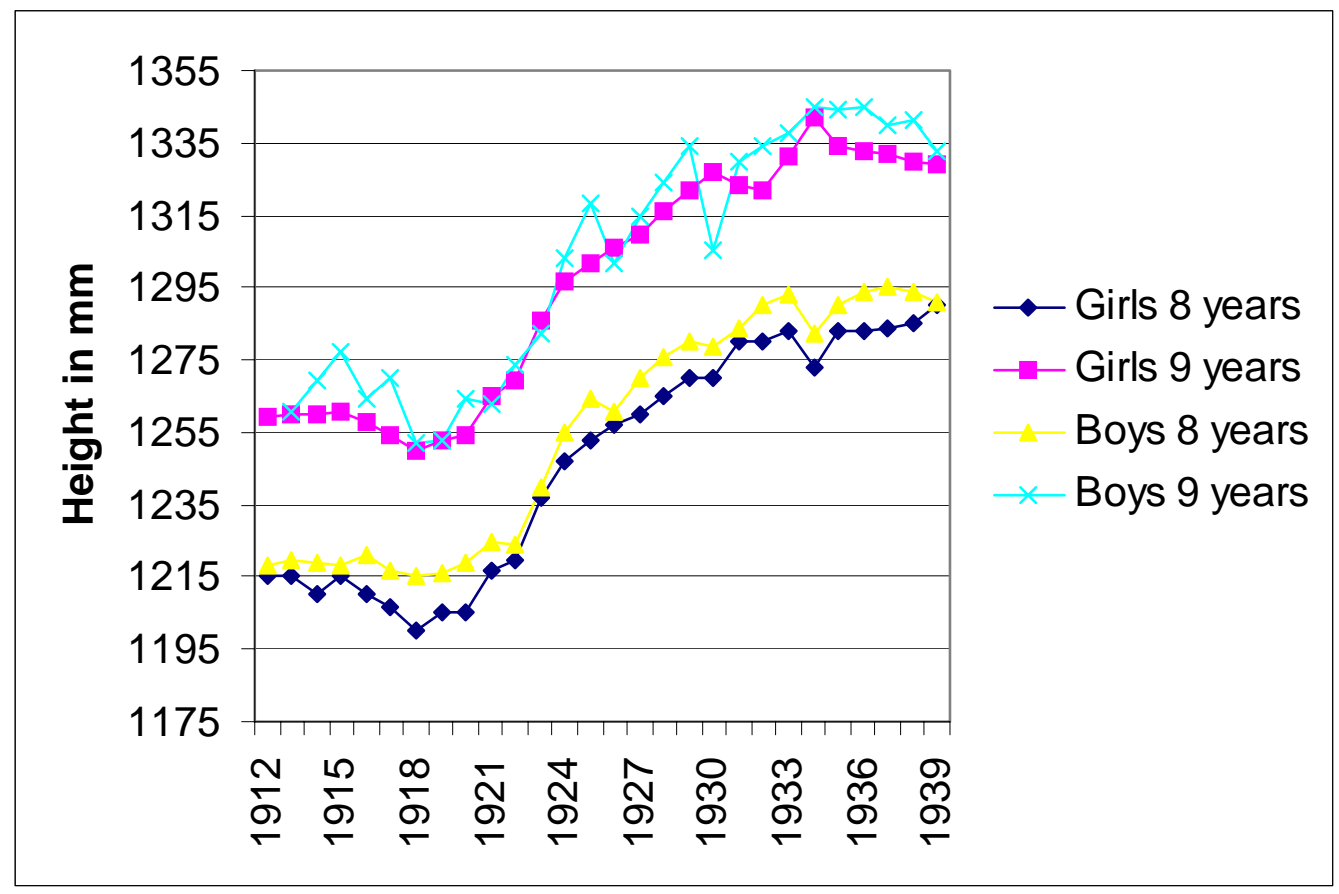

Source: Tanner (1990). 
Figure 2b: Heights of children in Leipzig (7.0 years old)

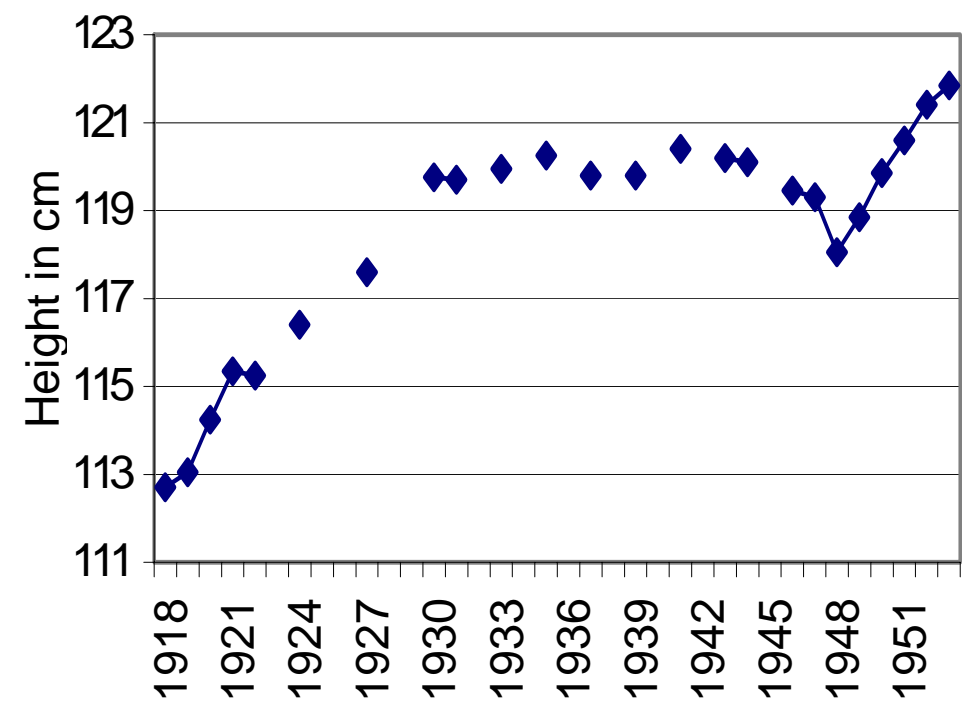

Source: Koch, E. (1953), cited after Marcusson (1962). The height data of children aged 6 year 9 months and 7 years 3 months were averaged.

After WWII, the German states developed radically differently in terms of productivity and purchasing power (van Ark 2001). What is less well-known, however, is that height and health were diverging as well. Komlos and Kriwy (2003) found, for example, that while East and West Germans born in the 1940s were of similar stature, those born in the GDR period fell significantly behind their Western counterparts (although an absolute height increase could be observed in both parts). Interestingly, social and gender differences were slightly smaller in the GDR, although social differences did not disappear, as was the official policy goal. After reunification, the heights of male children and even military conscripts in the East converged rapidly towards the higher Western level (Hermanussen 1995, 1997, Komlos and Kriwy 2003), although the exact dimension of the previous gap is still debated (Greil 1998).

Increasing heights were common in rich and well-developing countries over the $20^{\text {th }}$ century. Height increases have been observed in all European countries, and the upper limit might not have been reached until now. For example, Dutch heights - already the tallest in the 
world - still increased from $180 \mathrm{~cm}$ to no less than $184 \mathrm{~cm}$ on average in recent years. In contrast, countries with economic problems and unfavourable development conditions did not experience increases in height. For example, girl's heights in the Czech Republic have been stagnating during the difficult years after transition (Blaha et al. 2001). Children's stature in Kazakhstan - one of the former Soviet republics in Central Asia - has been stagnating or declining, with the height of girls developing even worse than boys' height due to religiouslyinduced discrimination in the labour market (Dangour 2003). ${ }^{1}$ Hence, the relationship between height and economic development is astonishingly pronounced for the late $20^{\text {th }}$ century, especially if intergenerational level effects and the influence of distinct nutritional traditions are taken into account.

\section{Data}

Anthropometric measurements from all Brandenburg school starters are available from 1994 onwards until 2006, with only the year 1996 missing (Table 2, panel A). ${ }^{2}$ The data were collected by public health services. All children in Brandenburg are medically examined by default before starting school. While medical examinations of school starters are carried out in other German Lands as well, what sets the data set at hand apart from all other German data sets is the inclusion of economic variables on parental occupational status, parental education, the number of siblings, and the number of adults living in the household. These data derive from an interview in the medical examination. During 1994-95, the first two years of examinations, the aforementioned socio-economic background variables were only recorded for half of the data set. However, this missing data problem resulted not from a selectivity of responses, but rather from the fact that some physicians avoided asking questions about unemployment and social background, fearing violations of data security or non-compliance.

\footnotetext{
${ }^{1}$ Moreover, in most of the poorly developing African countries, heights also developed poorly during the last three decades of the $20^{\text {th }}$ century (Moradi 2005).

${ }^{2}$ In 1996, the data was not collected due to internal reasons in the Ministry.
} 
However, we find no systematic distortion when comparing the share of "non-employment" responses with aggregated data. Until 2006 , more than $90 \%$ of the data are complemented with socio-economic background variables. The Brandenburg health reporting has been using these economic variables to assess the association between social inequality and infant morbidity from the late 1990s onwards (Böhm, Ellsäßer \& Kuhn 2003, MASGF 1999). Besides, an awareness of the health consequences of social inequality is growing among both experts and the general public.

Table 2: Descriptive statistics of the Brandenburg sample

\begin{tabular}{lrrr}
\hline Year & Boys & Girls & Total \\
\hline 1994 & 15,411 & 14,297 & 29,708 \\
1995 & 15,099 & 13,603 & 28,702 \\
1997 & 13,243 & 12,298 & 25,541 \\
1998 & 9,620 & 8,752 & 18,372 \\
1999 & 8,511 & 7,545 & 16,056 \\
2000 & 8,169 & 7,387 & 15,556 \\
2001 & 8,322 & 7,753 & 16,075 \\
2002 & 9,066 & 8,214 & 17,280 \\
2003 & 10,126 & 9,074 & 19,200 \\
2004 & 10,109 & 9,363 & 19,472 \\
2005 & 12,873 & 11,652 & 24,525 \\
2006 & 11,916 & 10,647 & 22,563 \\
Total & 132,465 & 120,585 & 253,050 \\
\hline & & & \\
\hline Age & Boys & Girls & Total \\
\hline 4 & 43 & 80 & 123 \\
5 & 39,660 & 39,745 & 79,405 \\
6 & 87,988 & 77,968 & 165,956 \\
7 & 4,691 & 2,725 & 7,416 \\
8 & 83 & 67 & 150 \\
Total & 132,465 & 120,585 & 253,050 \\
\hline & & &
\end{tabular}




\begin{tabular}{lrrr}
\hline Children in Househ. & Boys & Girls & Total \\
\hline 1 & 32,917 & 29,942 & 62,859 \\
2 & 46,351 & 42,144 & 88,495 \\
3 & 13,319 & 12,166 & 25,485 \\
4 & 3,974 & 3,688 & 7,662 \\
5 & 1,525 & 1,332 & 2,857 \\
6 & 591 & 553 & 1,144 \\
7 & 281 & 250 & 531 \\
8 & 102 & 102 & 204 \\
9 & 65 & 46 & 111 \\
11 & 13 & 14 & 27 \\
12 & 16 & 14 & 30 \\
Total & 99,154 & 90,251 & 189,405 \\
\hline
\end{tabular}

Note: Cases with unknown gender, height, or age were excluded. In the last table, cases with unknown number of children in household were excluded.

For all of the 253,050 children in the data set, height, gender, and age were recorded. The complete set of socio-economic variables was recorded for 166,387 cases. The quality of the anthropometric measurement can be rated high, since a standardized procedure was used. Initially, about 30,000 children were measured per year, but figures shrank to 15,000 to 25,000 children annually after 1998 . This was not the effect of selective measurement, but rather mirrors the demographic development of Brandenburg: while birth rates had already begun to decline during the GDR period of the 1980s, this trend was dramatically reinforced in the first half of the 1990s. Increasing pessimism about social and economic development, the higher average age of mothers and migration of young people led to a smaller frequency of births.

Most children in the data set were measured at age 6, while approximately one third were measured already at age 5. Some 7000 children were 7 years old, and negligible amounts were aged 4 and 8 . The typical family in Brandenburg over the period under study had either one or two children, with more children occurring relatively infrequently (Table 2, panel C). Finally, the employment and schooling characteristics of the parents need to be addressed: 
about two thirds of the school starters' mothers were employed. About $15 \%$ of the mothers had an Abitur degree (i.e. 12 years of successful schooling), while slightly less mothers finished not even 10 years of schooling.

\section{The development of unemployment and height}

The Land of Brandenburg is located around the German capital, Berlin. It experienced a remarkable positive economic development in the first half of the 1990s, with wages growing at $10-15 \%$ and GDP per capita even slightly more. There was modest convergence to Western Germany, albeit this was mostly due to large income transfers exactly from there. From the mid 1990s to the early 2000s, wages stopped growing and even declined somewhat after 2001. GDP per capita grew only modestly (around 2-3\%). This was typical of the entire eastern part of reunified Germany. In the second half of the 1990s, unemployment began to increase strongly and has hitherto remained at high levels.

Overall, the heights of 6-year-old boys increased from the GDR-times of the late 1980s (117.2 cm in a study by Greil \& Schilitz 1999) to $119.9 \mathrm{~cm}$ in 1997 (our study, age 6.0). In contrast, after 1997 there is a decline, followed by a very slight recovery (Figure 3). In assessing this time trend, we take great care to control for age in years and months (see the note under Figure 3). Interestingly, boys in Brandenburg were taller than girls in the period under study, which is not normally the case in this age range. In fact, none of the available growth reference charts for the U.S. suggests a height advantage for boys of this age (see http://www.cdc.gov/growthcharts/), although a recent German survey did (Stolzenberg et al.2007). The same phenomenon has been observed in other post-socialist societies (Dangour et al. 2003). Komlos and Kriwy (2003) note that male heights in Brandenburg improved more during and after reunification, as was the case in other areas of Eastern Germany (see also Schilitz 2001, Kromeyer, Hauspie and Susanne 1997). Zellner et al. (2004) postulate that the height of 7-year-old girls in Jena was $124.5 \mathrm{~cm}$ in 2001, whereas boys were $126.4 \mathrm{~cm}$ tall 
(Jena is situated in the Land of Thueringen, south-west of Brandenburg). These trends could be related to social behaviour, but might also have biological reasons (for example, some anthropologists have argued that female bodies are more robust in times of a difficult environment). We intend to address these issues in a separate study.

Figure 3. Height (in cm) of 6.0-year-old children from Brandenburg

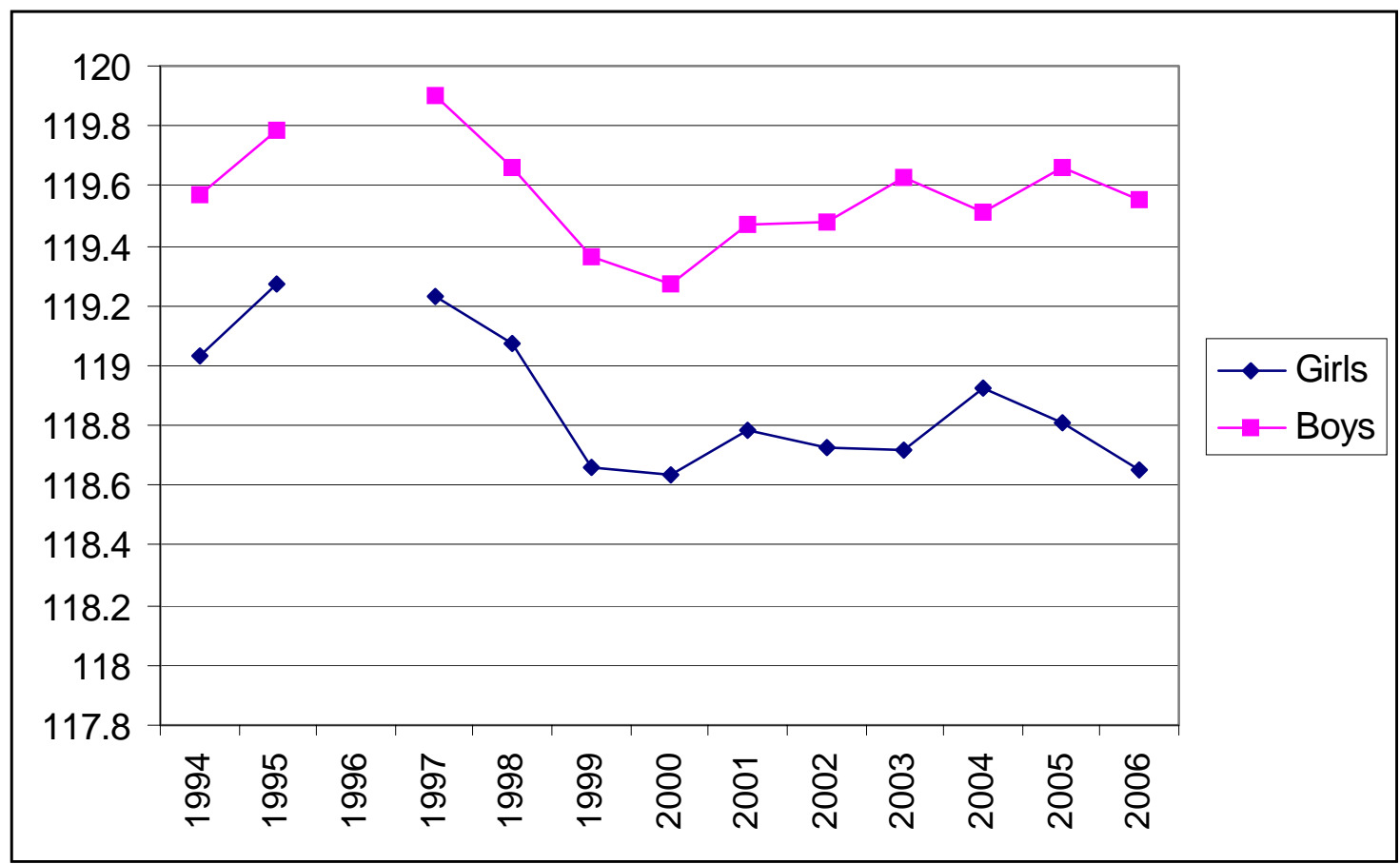

Note: This trend is adjusted for ages in months, and on the level of 6.0-year-olds, see regression A.1a and A.1b. The value for 1994 and 6.0-year-olds is represented by the constant, and the values for $1995 \mathrm{ff}$ is the constant plus the year coefficient, always for 6.0-year-olds. We control the age structure with month dummies, and include only 6.0-6.99-year-olds here. This is important, because if a disproportionately high number of children, say, aged 6 years and 11 months had been measured during the early phase, and a and many children aged 6 years and 1 month during the later phase, then simple averages could be misleading.

Next, we consider the correlation between parental occupational status and children's height, comparing the heights of children whose parents were reported as "both unemployed" versus "at least one parent employed" (Figure 4). Children of parents who were reported as "both unemployed" were always significantly shorter, by about $1.5 \mathrm{~cm}$ in 1995 and 1997, and still more than one centimetre in 2006. It is interesting to note, however, that the height of children with employed parents declined over this period. This might have been caused by 
external effects from the rising share of unemployment, either psychologically or as a result of the reduced purchasing power of the employed population (wages declined slightly in the later period). As the number of children with two unemployed parents also rose dramatically, the height reduction might indeed have been partially caused by this factor. Another potential explanation could be that an increasing number of children were living in single-parent households, which tend to be more vulnerable economically. However, we reject this variable, since the height decline of single-parent households was almost identical to the overall decline in height (Figure not shown, available from authors).

Figure 4: Height (cm) of female and male children (6.0 years old), with "both employed," versus "either employed" parents

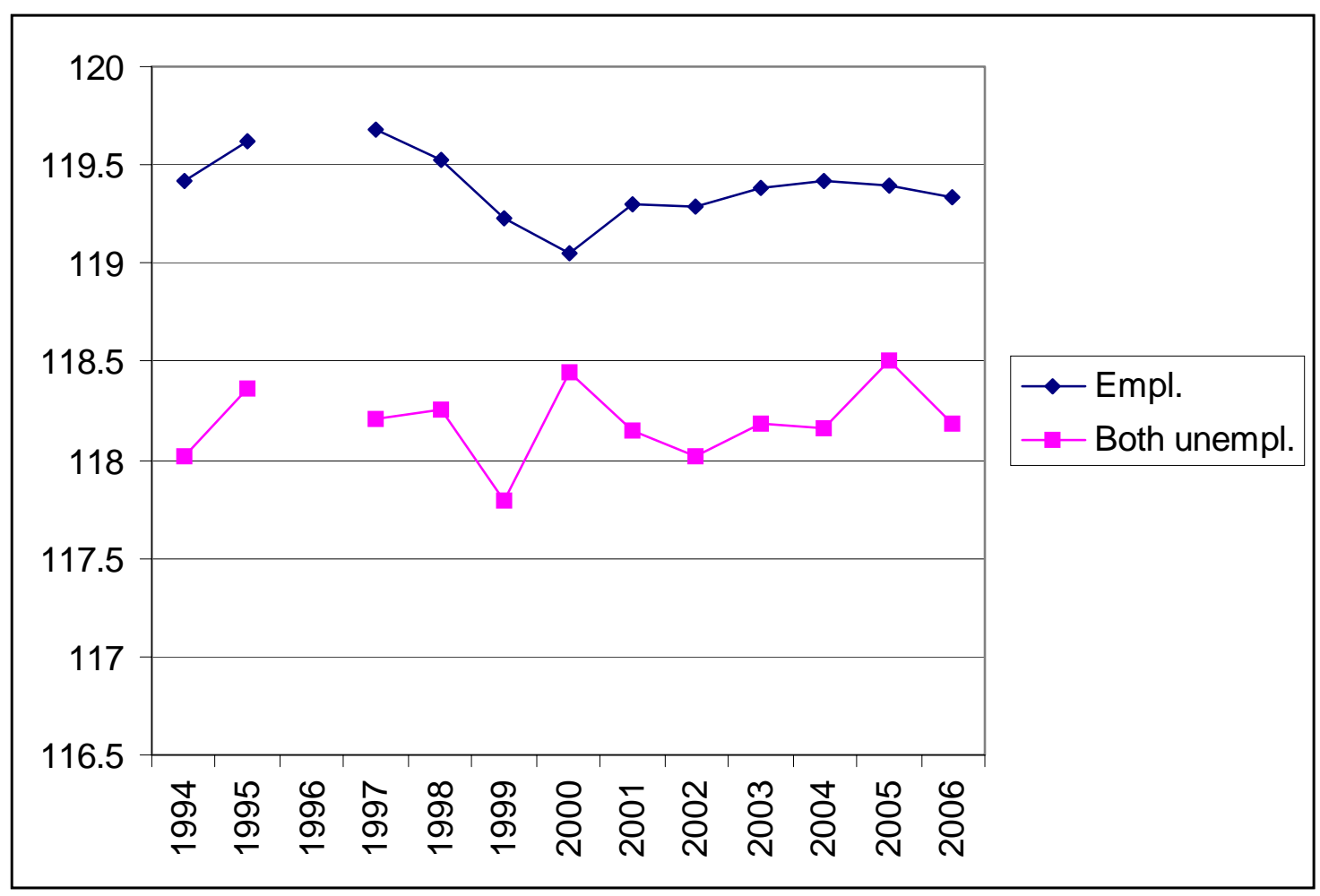

Note: Those trend are adjusted for ages in months, and on the level of 6.0-year-olds, see regression A.2. The value for 1994 and 6.0-year-olds is represented by the constant (minus the coefficient for unemployed parents in the lower line), and the values for 1995ff is the constant plus the year coefficient, always for 6.0-year-olds (with or without the unemployment coefficient subtracted). We control the age structure with month dummies, and include only 6.0-6.99-year-olds here. 


\section{The influence of parental unemployment (or employment) in districts with different development of unemployment}

Figure 5 compares employment and height in Brandenburg. Employment was initially high among parents in 1995 and 1997, but declined thereafter. In the years 2000 to 2003, there was a lower level stability around 83-85 percent for either parent employed. Heights followed suit, except for 2003-2006 when average heights were somewhat higher than expected, perhaps due to special health and welfare policies. Overall, heights decreased by about 0.6 centimeter, instead of continuing the secular upward trend. This reflects the problematic evolution of unemployment. This result is indeed compatible with the previous finding that the height of children with unemployed parents did not decline, since the share of unemployed parents was rising.

Figure 5: Height and employment of parents in all districts (two-axis-diagram; height in cm, 6.0 to 6.5-year-olds; share of employment of at least one parent)

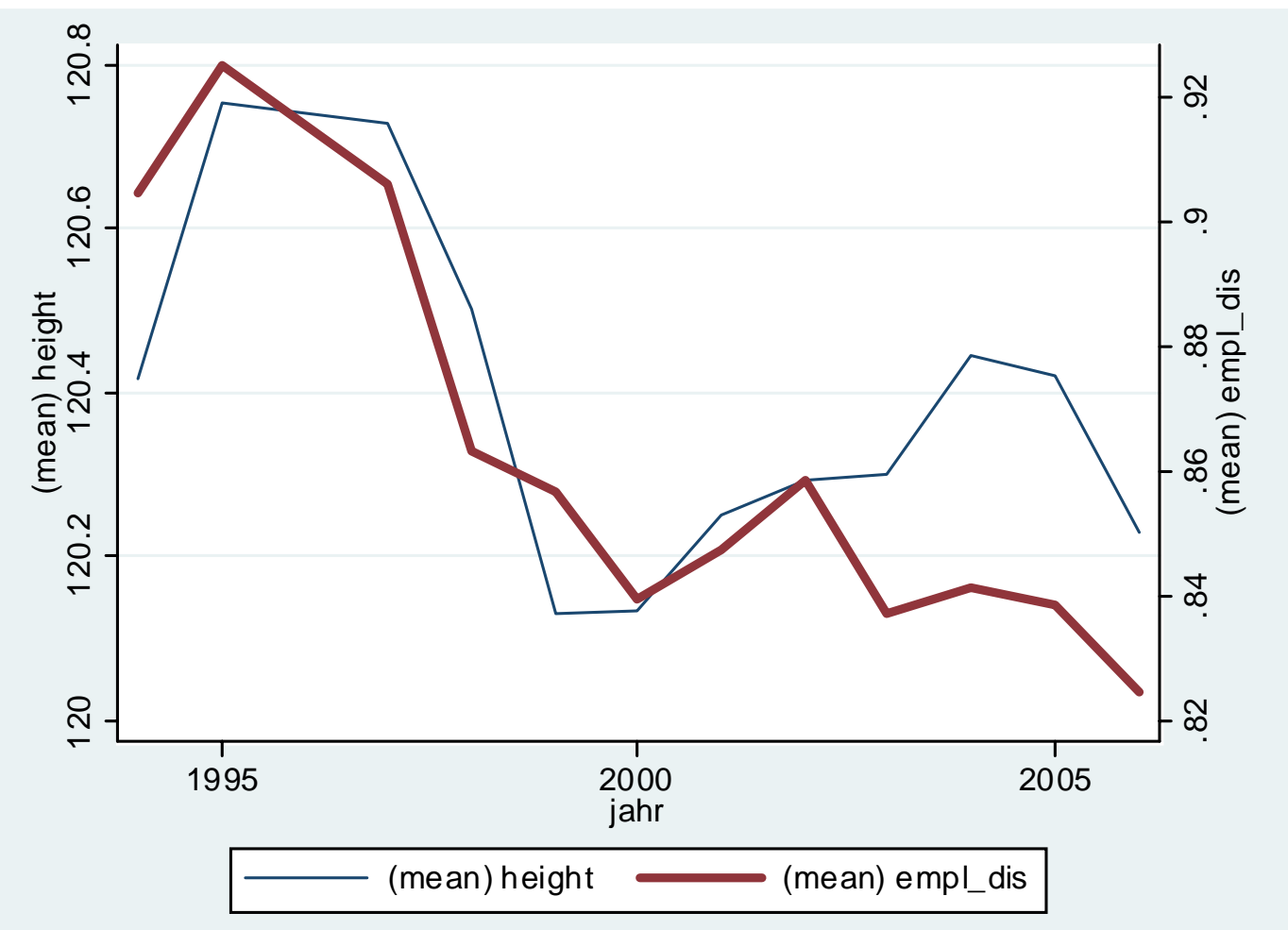


If we consider individual districts of Brandenburg, we observe more noise naturally (Figure 6 show four randomly selected districts). But still, the correlation between employment and height is given, particularly strong in the example district on the lower right. Note that the scales of both axes differ in order to account for different height elasticities in the two districts.

Figure 6: Height and employment of parents in four districts (height in cm, 6.0 to 6.5-yearolds; share of employment of at least one parent)
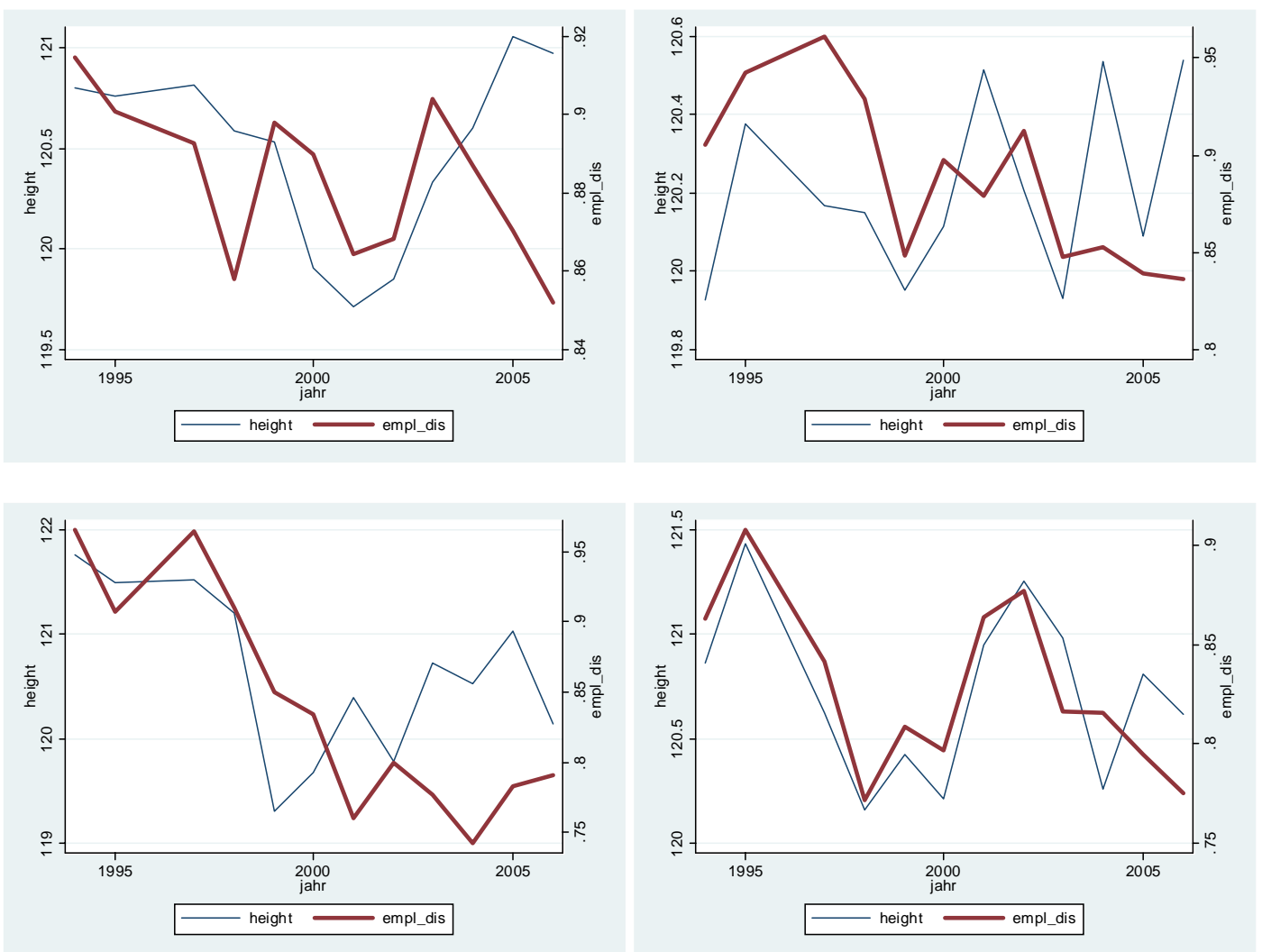

Given the graphical impression that employment influenced height levels even at the quite disaggregated district level, we now turn to a more systematic analysis, using panel regression techniques for districts, age-groups, and years (Table 3). In order to minimize measurement error from normal growth patterns, we distinguish three age groups: those aged 5.5-5.99 years, 6.0-6.49 years, and 6.5-6.00 years. Hence we obtain twelve annual 
observations for those 18 districts and three age groups. After discarding those with less than 100 height observations (as individual genetic variation should be averaged out sufficiently), we obtain 617 observations. We then regress heights with a least-square dummy variable model (equivalent to fixed effects), accounting for unobserved differences between districts and controlling for age groups. We find that unemployment had indeed a statistically significant influence on child stature (Table 3), although the coefficient is not very large. We also observe three outliers with unemployment rates of more than 40 percent, and interpret those as outlier. Re-estimating the equation in Model 2 of Table 3, we obtain a larger coefficient. We may conclude that unemployment mattered for the height of East German children, even at the quite disaggregate district level. In the next section, we will test the effect of (un-)employment on height on an individual basis, and control for a number of additional factors.

Table 3: Determinants of height on the district and age group level (panel with annual observations)

\begin{tabular}{lllll}
\hline Variable & Coeff. (1) & p-values & Coeff. (2) & p-values \\
\hline Incl. unempl. & all & & $<0.40$ & \\
rates & & & \\
\hline Estimator & LSDV & & LSDV & \\
Unemployment & -1.99 & 0.07 & -2.93 & 0.01 \\
Level of height & & & & \\
Constant & 117.93 & 0.00 & 118.11 & 0.00 \\
R-sq & 0.94 & & 0.0 .94 & \\
$\mathrm{~N}$ & 617 & & 614 & \\
\hline
\end{tabular}

Notes: all p-values estimated with robust estimator. LSDV: For each district, a dummy was included, except for one. Dummies for districts not reported. 


\section{Other determinants of height: trade-offs between care and purchasing power?}

We now turn to assess the influence of unemployment and other potential determinants on height at the individual level. In general, we expect a negative influence of unemployment on the health and social integration of a family, including the children (Table 4). The literature on the medical, psychological and social consequences of unemployment provides clear arguments for this relationship, and as our previous analysis has shown, the effects of unemployment on children's height can even be measured in an OECD country like Germany during the 1990s and 2000s. Simply put, the question is therefore whether the frustration of unemployment and the lower income of unemployed parents results in a reduced investment in their children, as in the form of allowing them unhealthy behaviour, and perhaps taking less care of them when they are ill - and whether this effect is so strong that it results in lower height even at the individual level in a rich country like Germany.

Table 4: Expected signs of the additional factors

\begin{tabular}{ll}
\hline Variable & Expected sign \\
\hline Unemployment & - \\
Interaction variables: & \\
Unempl * Number of siblings & - \\
Unempl * Adults in household & + \\
& \\
Other variables & $+/-$ \\
Number of siblings & + \\
Education of mother & + \\
Education of father & + \\
Number of adults in household & + \\
\hline
\end{tabular}

The immediate answer to this question is: "it depends" - for instance, on the number of people in the household who can provide additional income and care, or on the number of children who must be sustained with the unemployment income, and other similar factors. In 
what follows, we will assess the relationship between unemployment and other variables as well as their impact on children's height.

Firstly, a factor supplementing unemployment could be the number of children relying on the purchasing power and available energy for care-taking of the household. In other words, was children's height in Brandenburg reduced once additional children demanded care and nutrients? From an anthropological point of view, we would expect the opposite, since the second and futher children are usually shorter than the first child for biological reasons. Hence, we would ceteris paribus expect shorter children in one-child households. However, ceteris need not always be paribus. Our expectation for this variable is therefore not explicitly positive or negative per se, but when correlated with unemployment, we expect its marginal effect to be negative.

Secondly, we are interested in parental education, distinguishing between the mother's and father's education. With higher education, children could benefit from better health behaviour in general, and particularly from their parents' knowledge of the most appropriate food and health care items (Cigno 1991; Bogin 1988). In principle, one might also imagine that better-educated parents will face higher opportunity costs since they can expect higher incomes on the labour market, yet this effect does not seem strong enough to justify a mixed expectation. Hence, our expectation of education per se is positive.

Thirdly, we are able to measure the effect of additional adults living in the household. Clearly, it makes a difference whether or not only one adult has to take care of the offspring, while additional adults (such as grandmothers or other persons) can provide additional care to children. If the parents themselves are unemployed, additional adults may even be a source of further income. Our expectation of additional adults living in the household is therefore positive. 


\section{Results on the individual level}

Table 5 informs us about the individual effects of unemployment on children's height. Apart from age year dummies, dummies for age months were also included which had the expected magnitudes (not shown). We first discuss the simple effects (Model 1 and 2), then addressing interaction effects between unemployment and other variables (Model 3).

With the mother employed, a strong positive effect on children's height $(+0.78 \mathrm{~cm})$ was observable. This might be explained by higher income and, perhaps more importantly, the fact that employed mothers develop other desirable human capital characteristics. If the employment status of the father was not reported (which was typical for single female-headed households), the employment coefficient was even larger. The father's employment mattered slightly less for a child's height, although the coefficient still represents a remarkable +0.63 $\mathrm{cm}$. This serves also as an empirical "micro-foundation" for the results presented above, even if at the individual level, we cannot lag unemployment by one year.

In development economics, a frequent finding is that investments into female basic education has much stronger health effects than investments into male education, since females decide more often about health-related resources and care for children. We find the same tendency in our German sample: if mothers reported less than 10 years of schooling, children were 0.9 to $1.0 \mathrm{~cm}$ shorter (Model 2 and 3 in Table 5). If fathers reported the same schooling, the effect was negligible, except for a few cases in which data about the mother were reported as "unknown" (mostly single father-headed households). 
Table 5: Regressions of individual heights

\begin{tabular}{|c|c|c|c|}
\hline Regression (Model No.) & $(1)$ & $(2)$ & (3) \\
\hline \multicolumn{4}{|l|}{ Employment } \\
\hline \multirow[t]{2}{*}{ Moth. empl., fath. not miss. Data } & $0.78 * * *$ & $0.44 * * *$ & $0.43 * * *$ \\
\hline & $(0.00)$ & $(0.00)$ & $(0.00)$ \\
\hline \multirow[t]{2}{*}{ Moth. empl., fath. miss. Data } & $1.28 * * *$ & $0.73 * * *$ & $0.72 * * *$ \\
\hline & $(0.00)$ & $(0.00)$ & $(0.00)$ \\
\hline \multirow[t]{2}{*}{ Fath. empl. moth not miss. Data } & $0.63 * * *$ & $0.51 * * *$ & $0.40 * * *$ \\
\hline & $(0.00)$ & $(0.00)$ & $(0.00)$ \\
\hline \multirow[t]{2}{*}{ Fath. empl., moth. miss. Data } & $0.68 * * *$ & $0.57 * * *$ & $0.51 * * *$ \\
\hline & $(4.5 \mathrm{e}-09)$ & $(0.00014)$ & $(0.0012)$ \\
\hline \multicolumn{4}{|l|}{ Schooling of parents } \\
\hline \multirow[t]{2}{*}{ Moth. not 10 years, fath. not miss. d. } & & $-0.90 * * *$ & $-0.88 * * *$ \\
\hline & & $(0.00)$ & $(0.00)$ \\
\hline \multirow[t]{2}{*}{ Moth. not 10 years, fath. miss. data } & & $-0.78 * * *$ & $-0.80 * * *$ \\
\hline & & $(0.00)$ & $(0.00)$ \\
\hline \multirow[t]{2}{*}{ Fath. not 10 years, moth. not miss. d } & & $-0.08^{*}$ & -0.07 \\
\hline & & $(0.082)$ & $(0.16)$ \\
\hline \multirow[t]{2}{*}{ Fath. not 10 years, moth. miss. data } & & $-0.82 * * *$ & $-0.83 * * *$ \\
\hline & & $(0.0036)$ & $(0.0030)$ \\
\hline \multicolumn{4}{|l|}{ Household has... } \\
\hline \multirow[t]{2}{*}{2 children } & & $-0.44 * * *$ & $-0.41 * * *$ \\
\hline & & $(0.00)$ & $(0.00)$ \\
\hline \multirow[t]{2}{*}{3 children } & & $-1.01 * * *$ & $-0.93 * * *$ \\
\hline & & $(0.00)$ & $(0.00)$ \\
\hline \multirow[t]{2}{*}{4 and more children } & & $-1.79 * * *$ & $-1.74 * * *$ \\
\hline & & $(0.00)$ & $(0.00)$ \\
\hline \multirow[t]{2}{*}{1 adult } & & 0.07 & -0.06 \\
\hline & & $(0.12)$ & $(0.35)$ \\
\hline \multirow{3}{*}{ Interactions of unemployment } & & $0.23 * * *$ & $0.22 * * *$ \\
\hline & & & \\
\hline & & $(0.00055)$ & $(0.0014)$ \\
\hline \multirow[t]{2}{*}{ * 2 children } & & & $-0.26 * * *$ \\
\hline & & & $(0.00054)$ \\
\hline \multirow[t]{2}{*}{ * 3 children } & & & $-0.47 * * *$ \\
\hline & & & $(0.0000016)$ \\
\hline \multirow[t]{2}{*}{ * 4 and more children } & & & $-0.29 * *$ \\
\hline & & & $(0.012)$ \\
\hline \multirow[t]{2}{*}{ * 1 adult } & & & $0.29 * * *$ \\
\hline & & & $(0.0015)$ \\
\hline \multirow[t]{2}{*}{ * 3 and more adults } & & & -0.03 \\
\hline & & & $(0.89)$ \\
\hline
\end{tabular}




\begin{tabular}{llll}
\hline Other characteristics & & & \\
Female & $-0.68^{* * *}$ & $-0.70^{* * *}$ & $-0.70^{* * *}$ \\
Age 4 & $(0.00)$ & $(0.00)$ & $(0.00)$ \\
& 0.00 & 0.00 & 0.00 \\
Age 5 & () & () & () \\
& $4.97^{* * *}$ & $4.77^{* * *}$ & $4.79^{* * *}$ \\
Age 6 & $(0.00)$ & $(0.00)$ & $(0.00)$ \\
& $9.82^{* * *}$ & $9.73^{* * *}$ & $9.74^{* * *}$ \\
Age 7 & $(0.00)$ & $(0.00)$ & $(0.00)$ \\
& $11.89^{* * *}$ & $12.13 * * *$ & $12.15^{* * *}$ \\
Age 8 & $(0.00)$ & $(0.00)$ & $(0.00)$ \\
& $14.82^{* * *}$ & $14.97 * * *$ & $15.01^{* * *}$ \\
Constant & $(0.00)$ & $(0.00)$ & $(0.00)$ \\
& $112.82^{* * *}$ & $110.60^{* * *}$ & $110.68^{* * *}$ \\
Month dummies included? & $(0.00)$ & $(0.00)$ & $(0.00)$ \\
Observations & YES & YES & YES \\
Adjusted R-squared & 216186 & 166387 & 166387 \\
\hline
\end{tabular}

Note: Cases with unknown gender or age were excluded. This and missing information on employment and family structure accounts for the difference to the maximum number of cases. 11 dummies for each additional complete month of age were included, 0 month was the constant. Employment was not lagged here.

A third set of variables in Model 2 measures the number of children in the household. There is no evidence for the anthropological hypothesis that children of large families are taller (because the second and following children tend to be taller than the first). On the contrary, offspring of families with two or more children turned out shorter, since resources and care had to be shared - just like infectious illnesses might also have been shared more often. In households with two children, height was about half a centimeter lower than in onechild-households (represented by the reference group). Four and more children equalled as much as $1.8 \mathrm{~cm}$ less in height. Although one might be inclined to hypothesize that households with many children invest less in education, we found no significant correlation between children's height and the Abitur of the parents or the number of children in the household (Table 6). 
Table 6: Correlation of education and number of children

\begin{tabular}{lrr}
\hline & Mother 12+ & \multicolumn{2}{c}{ Father $12+$} \\
\hline 2 Children & 0.07 & 0.08 \\
3 Children & 0.01 & 0.03 \\
$4+$ Children & -0.04 & -0.03 \\
\hline
\end{tabular}

The number of adults was only significantly positive for households with three and more adults, so that a grandmother (or other adult) living in the household does indeed make a positive difference regarding child care. In contrast, single-headed households did not display lower heights of children. Finally, the puzzling fact that Eastern German girls were substantially shorter than male children of the same age was already been discussed above. The age dummy variables yield coefficients of a magnitude we would have expected.

In the next columns, we added the interaction terms with unemployment (Table 5, Model 3). When correlated with unemployment, single-headed households did have a small, but positive coefficient. Most of the single-household heads were women, who apparently used their additional time to take care of the children and appeared relatively robust against the frustration effects of unemployment (as opposed to households with unemployed males). The interaction terms of unemployment and additional children are remarkably large. Above, it was already shown that households with four and more children fall behind smaller households with regard to children's height, the former's children being significantly shorter $(-1.8 \mathrm{~cm})$. Now, the unemployment variable subtracts another height coefficient of $-0.3 \mathrm{~cm}$, in addition to the "normal" sibling effect! Hence, we conclude that the interaction terms with unemployment are important components of our empirical model, even if the adjusted Rsquare does not increase. 


\section{Could educational trends of mothers, the number of siblings, or health spending explain}

\section{the height trends?}

The individual results presented above are certainly interesting in themselves, yet what is of particular interest to us is whether these factors can explain the negative height trend after 1997 described at the beginning of this paper. It turns out that this is not the case. To give just one example, the education of mothers has now even shifted towards the higher schooling categories (Table 7): thus, the share of mothers with 12 and more years of successful schooling (Abitur) has increased from 12 to 22\%, whereas the share with less than 10 years of schooling has declined slightly from 10 to 7 percent. The share of highly educated fathers has grown from 10 to 19 per cent. The number of children in a household (in our group) has remained constant in this data set, varying very modestly between 1.92 and 2.05. In a similar vein, health spending is probably not the main determinant of declining children's height in Brandenburg. The numbers of hospital beds per population slightly declined, but the effects of hospital on pre-school children are probably not large -- unless the slight decline indicates a general decline of health spending. But this is unlikely, as the number pf physicians per capita rather increased over time (Table 7).

Table 7: Schooling and health characteristics of parents and number of children

\begin{tabular}{|c|c|c|c|c|c|c|}
\hline \multirow[t]{2}{*}{ Year } & \multicolumn{3}{|c|}{ Schooling in years } & \multirow{2}{*}{$\begin{array}{r}\text { Children } \\
\text { (household) }\end{array}$} & \multirow{2}{*}{$\begin{array}{r}\text { Hospital } \\
\text { beds }\end{array}$} & \multirow[t]{2}{*}{ Physician } \\
\hline & Moth $<10$ & Mother $12+$ & Father $12+$ & & & \\
\hline 1994 & 0.10 & 0.10 & 0.10 & n.a & 6.99 & 2.50 \\
\hline 1995 & 0.07 & 0.08 & 0.08 & n.a & 6.81 & 2.59 \\
\hline 1997 & 0.09 & 0.09 & 0.09 & 1.93 & 6.75 & 2.65 \\
\hline 1998 & 0.10 & 0.10 & 0.10 & 2.00 & 6.62 & 2.69 \\
\hline 1999 & 0.10 & 0.13 & 0.13 & 2.02 & 6.37 & 2.74 \\
\hline 2000 & 0.11 & 0.15 & 0.15 & 2.05 & 6.32 & 2.77 \\
\hline 2001 & 0.11 & 0.17 & 0.17 & 2.01 & 6.27 & 2.79 \\
\hline 2002 & 0.10 & 0.18 & 0.18 & 2.01 & 6.22 & 2.85 \\
\hline 2003 & 0.09 & 0.20 & 0.20 & 1.99 & 6.21 & \\
\hline
\end{tabular}




\begin{tabular}{llllll}
\hline 2004 & 0.09 & 0.21 & 0.21 & 1.98 & 6.08 \\
2005 & 0.08 & 0.20 & 0.19 & 1.95 & 6.05 \\
2006 & 0.07 & 0.22 & 0.19 & 1.92 & 6.02 \\
\hline
\end{tabular}

Notes: column 2 to 4 are shares, i.e. 0.10 means 10\%. Hospital beds are per 100,000 inhabitants, physicians also per \# population. Source: Statistik Regional Brandenburg (www.statistik.brandenburg.de); Degner (2006).

\section{Conclusion}

The main finding of this study is that, somewhat contrary to our expectations, unemployment mattered for the height of young children in Eastern Germany, 1994-2006. Our result that parental unemployment renders children between one and two centimeters shorter, even after controlling for a number of other potential determinants, has substantial economic, political and social implications.

Could endogeneity have played a role here in that shorter parents, who genetically tend to have shorter children, ended up more often in unemployment? After all, Hamermesh et al. (1994) have shown that individual height matters for income, hence it could also matter for employment prospects. However, as was shown above, unemployment matters also over time and at the district level. In the district-time panel, individual genetic height dispersion averaged out, and should not impact on changes in height. In addition, the timing is important here: while the height of 6-year-old children is strongly influenced by the year before measurement, a potential genetic height effect should already have been transmitted at the time of conception seven years earlier. Moreover, in the study on the UK cited above, Rona and Chinn (1991) controlled for the height of parents, and still found an independent influence of unemployment of $1.2 \mathrm{~cm}$.

What are the wider implications of this research? Firstly, it is important to consider new measures for the effects of unemployment. Children's height can be used as a sensitive social indicator, since height is correlated with health and longevity and is hence a proxy for important components of the human utility function (Fogel 1993, Waaler 1984). Income, in 
contrast, is to a certain extent an input to utility - more income does correlate with higher utility, but the correlation is far from perfect. For example, health-related public goods might be accessible to, or even free of charge for unemployed people in some regions, in which case income would matter less. Moreover, utility as derived from household income might be unequally distributed among the various household members, thus making household structure another important factor in this regard. For example, we found in this study that children's height is very sensitive to the number of siblings. A 6-year-old Brandenburg child entering school is on average $1.8 \mathrm{~cm}$ shorter if it has three or more siblings. In addition, if the parents are unemployed, the detriment is even larger.

Results from social epidemiology show the association between the health status and the social status. That's true for adults and children. Therefore the World Health Organisation (WHO) says that epidemiologic studies and health reporting should always include socioeconomic variables (Kunst and Mackenbach 1995). From an anthropometric point of view we suggest the use socioeconomic data to understand secular changes of height. In the important debate over the effects of unemployment, such a measure is certainly a step forward and we would suggest that socioeconomic variables should not only be collected for Brandenburg, but for all countries. In this study, we used for the first time a unique data set which is as of now not available for other countries of the world. Hence, we would argue that a more systematic collection of such data - at low marginal costs, since children entering school are measured anyway - could yield important information about the success of public health infrastructure investments and deepen our understanding of the relationship between unemployment and the biological components of welfare. 


\section{References}

Ark, Bart van (2001), 'Convergence and Divergence in the European Periphery: Productivity in Eastern and Southern Europe in Retrospect,' in Bart van Ark and Nicholas Crafts (eds.), Quantitative Aspects of Post-war European Economic Growth (Cambridge: Cambridge University Press), pp. 271-326.

Baten, Joerg, and Andrea Wagner (2003), "Autarky, Market Disintegration, and Health: The Mortality and Nutritional Crisis in Nazi Germany 1933-37", in Economics and Human Biology 1-1, pp. 1-28.

Bláha, P, J. Vignerová, J. Kobzová, L. Krejčovský and J. Riedlová, VI. Celostátní antropologický výzkum dětí a mládeže (6th Nation-wide Anthropological Survey of Children and Adolescents 2001), Česko-slovenská Pediatr. 12 (2001), pp. 766-770.

Bogin (1988), Patterns of Human Growth. Cambridge et al.

Böhm, A., Ellsäßer, G. \& Kuhn, J. (2003), Arme Kinder, kranke Kinder? Was man aus Einschulungsuntersuchungen alles lernen kann, in Mabuse, 45, 18-19.

Cigno, A. (1991), Economics of the Family, Clarendon Press, Oxford.

Degner, H. (2006). Der Lebensstandard in Ostdeutschland nach der Wiedervereinigung. Unpublished Diplom Thesis Tuebingen.

Dohmen, T., Falk, A., Huffman, D., Schupp, J., Sunde, U., Wagner, G.G. (2006). Individual Risk Attitudes: New Evidence from a Large, Representative, ExperimentallyValidated Survey. CEPR Disc Paper 5517.

Dangour, Alan / A. Farmer / H.L. Hill / S.J. Ismail (2003), 'Anthropometric Status of Kazakh Children in the 1990s', in Economics and Human Biology 1, pp. 43-53.

Fogel, Robert W. (1993), New Sources and New Techniques for the Study of Secular Trends in Nutritional Status, Health, Mortality, and the Process of Aging, in Historical Methods 26-1, pp. 5-43. 
Goerke, L., Pannenberg, M. (2007). Risk Aversion and Trade Union Membership. Working Paper Univ. Tuebingen/DIW Berlin.

Greil, Holle (1998), 'Age- and Sex-specifity of the Secular Trend in Height in East Germany', in Komlos, John and Joerg Baten (eds.), The Biological Standard of Living in Comparative Perspective. Stuttgart, pp. 483-496.

Greil, H, and A. Schilitz (1999), Koerperbau und koerperlicher Entwicklungsstand von Brandenburger Schülern und Schülerinnen am Ende des 20. Jahrhunderts, in: Helmke, Ch., P. Haase, and C.U. Rückert (eds.), Zur Situation des Schulsports im Lande Brandenburg und Wege zur Erhoehung seiner Qualitaet. Potsdam.

Hamermesh, D.S., and J. Biddle (1994), "Beauty and the Labor Market," American Economic Review, 18-5, p. 1174-1194.

Hermanussen, M. (1995), 'Die Körpergröße deutscher Wehrpflichtiger vor und nach der deutschen Wiedervereinigung', in Die Medizinische Welt 46, 391-392.

Hermanussen, M. (1997), 'Catch-up in Final Height after Unification of Germany', in Acta Medica Auxologica 29(3), 135-141.

Jaeger, U., Zellner, K., Kromeyer, K. (1990). Ergebnisse Jenaer anthropologischer Schulkinderuntersuchungen zwischen 1880 und 1985. Anthropol. Anz. 48, 239-245. Komlos, John (1996), Anomalies in Economic History: Towards a Resolution of the ‘Antebellum' Puzzle, in Journal of Economic History 56, 1, 202-14.

Komlos, John, (1989), Nutrition and Economic Development in the Eighteenth Century Habsburg Monarchy: An Anthropometric History. Princeton University Press, Princeton.

Komlos, J. (1999), 'On the Biological Standard of Living in Russia and the Soviet Union', in Slavic Review 58(1) (Spring), 71-79.

Komlos, John, and Peter Kriwy (2003), “The Biological Standard of Living in the Two Germanies", in German Economic Review 4-4, pp. 459-473. 
Kromeyer, K., R. C. Hauspie and C. Susanne (1997), 'Socioeconomic Factors and Growth during Childhood and Adolescence in Jena Children', in Annals of Human Biology 24(4), 343-353.

Kunst A.E., Mackenbach J.P. (1995), Measuring socioeconomic inequalities in health. Copenhagen: World Health Organisation.

MASGF (1999), Einschüler in Brandenburg: Soziale Lage und Gesundheit. Potsdam: Ministerium für Arbeit, Soziales, Gesundheit und Frauen. www.masgf.brandenburg.de.

Moradi (2005), Ernährung, wirtschaftliche Entwicklung und Bürgerkriege in Afrika südlich der Sahara (1950-2000). Dissertation Univ. Tuebingen available at www.ub.unituebingen.de.

Rona, R.J., Chinn, S. (1991), “Father's Unemployment and Height of Primary School Children in Britain”, Annals of Human Biology 18-5, pp. 441-448.

Schilitz, A. (2001), Körperliche Entwicklung und Körperzusammensetzung von Brandenburger Schulkindern im Geschlechter- und Altersgruppenvergleich, Shaker, Aachen.

Statistik Regional Brandenburg (www.statistik.brandenburg.de).

Steckel, R., Floud, R. (1997) (eds.), Health and Welfare During Industrialization. University of Chicago Press, Chicago, pp. 331-77.

Stolzenberg, H., Kahl, H., Bergmann, K.E. (2007). Körpermaße bei Kindern und Jugendlichen in Deutschland. Ergebnisse des Kinder- und Jugendgesundheitssurveys (KiGGS). Bundesgesundheitsbl - Gesundheitsforsch - Gesundheitsschutz 2007 . 50:659-669 DOI 10.1007/s00103-007-0227-5

Tanner, J. (1990), Fetus into Man: Physical Growth from Conception to Maturity, Harvard University Press, Cambridge, MA (revised edition, first published in 1978). 
Waaler, Hans (1984), Height, Weight, and Mortality: The Norwegian Experience, in Acta Medica Scandicana (Suppl.) 679, p. 1-56.

Zellner, K., K. Kromeyer and U. Jaeger (1996), 'Growth Studies in Jena, Germany: Historical Background and Secular Changes in Stature and Weight in Children 7-14 Years', in American Journal of Human Biology 8, 371-382.

Zellner, K., U. Jaeger, and K. Kromeyer-Hausschildt (2004), in Economics and Human Biology 2-2. 
Appendix Table A.1a (Girls) (not to be published, only for referee information) . reg groesse_Ijahr*_Ialterm* if geschl==2 \& alterj==6

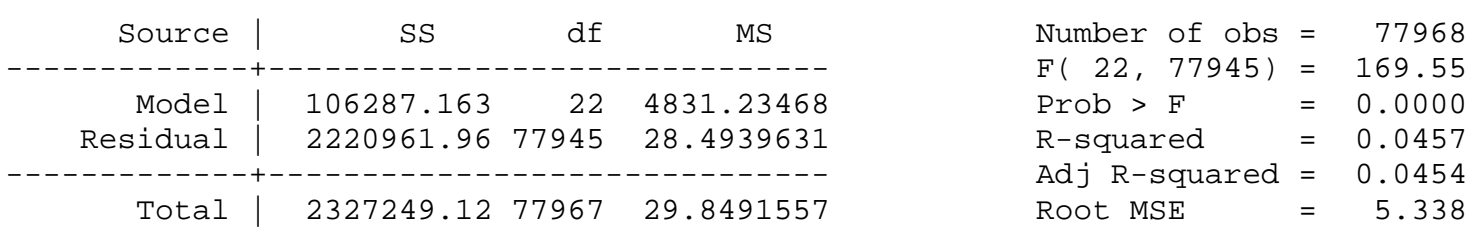

\begin{tabular}{|c|c|c|c|c|c|c|}
\hline groesse & Coef & Std. Err & $\mathrm{t}$ & $P>|t|$ & [95\% Conf & Interval] \\
\hline 1995 & 2422183 & 075448 & 3.21 & 0.001 & 3405 & 3900 \\
\hline Ijahr_1997 & 2021041 & .0763902 & 2.65 & 0.008 & .0523796 & 3518285 \\
\hline Ijahr_1998 & .0397675 & .0865792 & $\odot .46$ & 0.646 & -.1299272 & 2094622 \\
\hline Ijahr 1999 & -.373324 & .0914899 & -4.08 & $\odot .00 \odot$ & -.5526438 & -.1940043 \\
\hline 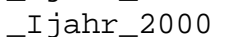 & $-.40 \odot 4693$ & .0935747 & -4.28 & $\odot . \odot \odot \odot$ & -.5838753 & -.2170634 \\
\hline Ijahr_2001 & $-.250 \odot 431$ & $.09 \odot 887$ & -2.75 & $\odot .0 \odot 6$ & - . 4281812 & - . . 071905 \\
\hline Ijahr_2002 & -.3076674 & . 0897057 & -3.43 & $\odot .001$ & -.4834901 & -.1318448 \\
\hline _Ijahr_2003 & -.3134086 & .0880553 & -3.56 & $\odot .00 \odot$ & - . 4859965 & -.1408208 \\
\hline Ijahr 2004 & -.1075507 & .0874505 & -1.23 & $\odot .219$ & -.2789531 & .0638517 \\
\hline Ijahr 2005 & - . 2198677 & .0869568 & -2.53 & 0.011 & -.3903026 & -.0494328 \\
\hline Ijahr 2006 & -.3780604 & .0933386 & -4.05 & $\odot .0 \odot \odot$ & $-.5610 \odot 36$ & -.1951173 \\
\hline Ialterm 1 & .3766911 & .0835039 & 4.51 & $\odot .0 \odot \odot$ & .2130239 & .5403582 \\
\hline Ialterm 2 & .9019494 & .0836285 & 10.79 & $\odot .0 \odot \odot$ & .738038 & 1. 065861 \\
\hline Ialterm 3 & 1.287317 & .0837414 & 15.37 & $\odot .0 \odot \odot$ & 1.123185 & 1.45145 \\
\hline _Ialterm_4 & 1.919224 & .0839825 & 22.85 & $\odot .00 \odot$ & 1.754619 & 2.08383 \\
\hline _Ialterm_5 & 2.395722 & .0843801 & 28.39 & $\odot . \odot \odot \odot$ & 2.230337 & 2.561107 \\
\hline _Ialterm_6 & 2.828889 & .084602 & 33.44 & $\odot .000$ & 2.663069 & 2.994708 \\
\hline _Ialterm_7 & 3.144642 & .0865667 & 36.33 & 0.000 & 2.974972 & 3.314313 \\
\hline _Ialterm_8 & 3.404826 & .0949496 & 35.86 & $\odot .0 \odot \odot$ & 3.218725 & 3.590926 \\
\hline Ialterm_9 & 3.159056 & .1142494 & 27.65 & $\odot .0 \odot \odot$ & 2.935128 & 3.382984 \\
\hline Ialterm_10 & 2.747199 & .1459263 & 18.83 & $\odot . \odot \odot \odot$ & 2.461184 & 3.033214 \\
\hline Ialterm 11 & 2.565854 & .1740343 & 14.74 & $0.00 \odot$ & 2.224748 & 2.90696 \\
\hline cons & 119.0328 & .0771108 & 1543.66 & $0.00 \odot$ & 118.8817 & 119.1839 \\
\hline
\end{tabular}

Appendix Table A.1b (Boys)

. reg groesse_Ijahr* _Ialterm* if geschl==1 \& alterj==6

\begin{tabular}{|c|c|c|c|c|c|}
\hline Source I & SS & $d f$ & MS & Number of obs & 87988 \\
\hline & & & & $F(22,87965)$ & 206.09 \\
\hline Model & 130067.296 & 22 & 5912.14983 & Prob > F & $\odot .000 \odot$ \\
\hline Residual & 2523519.99 & 87965 & 28.6877735 & R-squared & 0.0490 \\
\hline Total & 2653587.29 & 87987 & 30.1588563 & $\begin{array}{l}\text { Adj R-squared } \\
\text { Root MSE }\end{array}$ & $\begin{array}{l}0.0488 \\
5.3561\end{array}$ \\
\hline
\end{tabular}

\begin{tabular}{|c|c|c|c|c|c|c|}
\hline groesse & Coef. & Std. Err. & $\mathrm{t}$ & $P>|t|$ & [95\% Conf. & Interval] \\
\hline _Ijahr_1995 & 2153079 & .0719842 & 2.99 & $\odot .003$ & .0742196 & .3563963 \\
\hline Ijahr_1997 & .3297403 & .0737028 & 4.47 & $\odot . \odot \odot \odot$ & .1852835 & .4741971 \\
\hline IJjahr_1998 & .0953363 & .0832064 & 1.15 & $\odot .252$ & -.0677475 & .2584201 \\
\hline _Ijahr_1999 & -.2032077 & .0858177 & -2.37 & ๑.018 & - . 3714097 & - . 0350058 \\
\hline Ijahr_200๑ & - . 2983015 & .0880374 & -3.39 & $\odot . \odot \odot 1$ & -.470854 & -.125749 \\
\hline Ijahr_2001 & - . .0977939 & .0872559 & -1.12 & 0.262 & -.2688147 & .0732269 \\
\hline _Ijahr_2002 & - . 0884958 & .0850233 & -1.04 & $\odot .298$ & -.2551407 & .078149 \\
\hline _Ijahr_2003 & .0553836 & .0825014 & 0.67 & $\odot .502$ & -.1063184 & .2170856 \\
\hline Ijahr_2004 & -.0584318 & .0830843 & -0.70 & $\odot .482$ & -.2212762 & .1044126 \\
\hline _Ijahr_2005 & .0907934 & .0819649 & 1.11 & $\odot .268$ & -.069857 & .2514439 \\
\hline _Ijahr_20๑6 & - . 0175115 & .0866648 & -0.20 & $\odot .84 \odot$ & -.1873736 & .1523507 \\
\hline Ialtērm_1 & .3375564 & .0814331 & 4.15 & $\odot .00 \odot$ & .1779483 & .4971646 \\
\hline _Ialterm_2 & .7938773 & .0814254 & 9.75 & $\odot .00 \odot$ & .6342842 & .9534703 \\
\hline _Ialterm_3 & 1.287383 & .081551 & 15.79 & $\odot .00 \odot$ & 1.127544 & 1.447222 \\
\hline _Ialterm_4 & 1.889283 & .0811089 & 23.29 & $\odot .00 \odot$ & 1.73031 & 2.048256 \\
\hline _Ialterm_5 & 2.442661 & .08119 & 30.09 & $\odot .00 \odot$ & 2.283529 & 2.601793 \\
\hline _Ialterm_6 & 2.923565 & .0813038 & 35.96 & $\odot .00 \odot$ & 2.76421 & 3.08292 \\
\hline _Ialterm_7 & 3.127845 & .0823344 & 37.99 & $\odot .00 \odot$ & 2.96647 & 3.28922 \\
\hline _Ialterm_8 & 3.458391 & .0875162 & 39.52 & $\odot .00 \odot$ & 3.28686 & 3.629922 \\
\hline
\end{tabular}




\begin{tabular}{r|rrrrrr} 
Ialterm_9 & 3.525955 & .1013637 & 34.79 & $0.0 \odot \odot$ & 3.327283 & 3.724627 \\
-Ialterm_10 & 3.148111 & .1239378 & $25.4 \odot$ & $0.0 \odot \odot$ & 2.905194 & 3.391028 \\
-Ialterm_11 & 2.883344 & .1445639 & 19.95 & $0.00 \odot$ & 2.6 & 3.166688 \\
_cons & 119.5684 & .0745573 & 1603.71 & $0.00 \odot$ & 119.4223 & 119.7145
\end{tabular}

Appendix Table A.2

- reg groesse_Ijahr* u_Ijahr*_Ialterm* if alterj==6

\begin{tabular}{|c|c|c|c|c|}
\hline Source I & SS & MS & $\begin{array}{l}\text { Number of obs } \\
F(34,166775)\end{array}$ & $\begin{array}{l}166810 \\
275.44\end{array}$ \\
\hline Model & 267616.316 & 7871.06811 & Prob > F & 0.0000 \\
\hline Residual & 4765843.83166775 & 28.5764882 & $\begin{array}{l}\text { R-squared } \\
\text { Adj R-squared }\end{array}$ & $\begin{array}{l}0.0532 \\
0.0530\end{array}$ \\
\hline Tota] & 5033460.14166809 & 30.1749914 & Root MSE & 5.3457 \\
\hline
\end{tabular}

\begin{tabular}{|c|c|c|c|c|c|c|}
\hline groesse & Coef. & Std. Err. & $\mathrm{t}$ & $P>|t|$ & {$\left[\begin{array}{ll}95 \% & \text { Conf }\end{array}\right.$} & Interval] \\
\hline Ijahr_1995 & 1971907 & .0538152 & 3.66 & $\odot . \odot \odot \odot$ & .091714 & .3026673 \\
\hline Ijahr_1997 & 2636989 & .0551946 & 4.78 & $\odot .000$ & 1555187 & 3718791 \\
\hline Ijahr_1998 & 1021859 & .0634567 & 1.61 & $\odot .107$ & - . . 0221879 & 2265597 \\
\hline Ijahr_1999 & -1902106 & .06672 & -2.85 & $\odot .004$ & -.3209804 & -.0594408 \\
\hline Ijahr_200९ & -.3703716 & .0686423 & -5.40 & $\odot .000$ & -.504909 & -.2358342 \\
\hline Ijahr_2001 & -.1250355 & .067276 & -1.86 & $\odot .063$ & - . 2568951 & .006824 \\
\hline _Ijahr_2002 & -.1370352 & .0655858 & -2.09 & 0.037 & -.265582 & - .0084884 \\
\hline _Ijahr_2003 & -.036527 & .0644447 & $-\odot .57$ & 0.571 & -.1628372 & .0897832 \\
\hline _Ijahr_20๑4 & - .0009899 & .0644643 & -0.02 & 0.988 & -.1273386 & 3587 \\
\hline Ijahr_2005 & - . .0230099 & .0638949 & -0.36 & $\odot .719$ & -.1482426 & . 1022227 \\
\hline Ijahr_2006 & - . . 9905832 & .0683858 & -1.32 & $\odot .185$ & - . 2246179 & 4515 \\
\hline u_Ijahr_1995 & -1.260016 & .1433742 & -8.79 & $\odot .00 \odot$ & -1.541026 & -.97 \\
\hline u_Ijahr_1997 & -1.477492 & .1386431 & -10.66 & $\odot .000$ & -1.749229 & -1.205754 \\
\hline u_Ijahr_1998 & -1.262414 & .1430818 & -8.82 & $\odot . \odot \odot \odot$ & -1.542851 & -.981977 \\
\hline u_Ijahr_1999 & -1.435537 & .1445227 & -9.93 & $\odot .000$ & -1.718798 & -1.152276 \\
\hline u_Ijahr_2000 & -.6081763 & .146385 & -4.15 & $\odot . \odot \odot \odot$ & -.8950877 & -.321265 \\
\hline u_Ijahr_2001 & -1.144215 & .1434925 & -7.97 & $\odot .000$ & -1.425457 & - .8629727 \\
\hline u_Ijahr_2002 & -1.262577 & .1445207 & -8.74 & $\odot .000$ & -1.545834 & -.9793195 \\
\hline u_Ijahr_2003 & -1.197844 & .1312343 & -9.13 & $\odot . \odot \odot \odot$ & -1.45506 & -.9406272 \\
\hline u_Ijahr_2004 & -1.260682 & .1316952 & -9.57 & $\odot . \odot \odot \odot$ & -1.518802 & $-1.0 \odot 2562$ \\
\hline u_Ijahr_2005 & -.8875693 & .1283327 & -6.92 & $\odot . \odot \odot \odot$ & -1.139098 & $-.636 \odot 401$ \\
\hline u_Ijahr_2006 & -1.149684 & .1379967 & -8.33 & $\odot . \odot \odot \odot$ & -1.420154 & -.8792131 \\
\hline u_Ijahr_1994 & -1.400753 & .1234363 & -11.35 & $\odot . \odot \odot \odot$ & -1.642685 & -1.158821 \\
\hline Ialterm_1 & .3508571 & .0581252 & 6.04 & $\odot . \odot \odot \odot$ & .236933 & .4647813 \\
\hline Ialterm_2 & .8498167 & .0581471 & 14.61 & $\odot .00 \odot$ & .7358497 & .9637837 \\
\hline Ialterm_3 & 1.291753 & .0582391 & 22.18 & $\odot . \odot \odot \odot$ & 1.177605 & 1.4059 \\
\hline Ialterm_4 & 1.912549 & .0581648 & 32.88 & $\odot .0 \odot \odot$ & 1.798548 & 2.026551 \\
\hline _Ialterm_5 & 2.427585 & .058319 & 41.63 & $\odot . \odot \odot \odot$ & 2.313281 & 2.541889 \\
\hline _Ialterm_6 & 2.888148 & .0584471 & 49.41 & $\odot . \odot \odot \odot$ & 2.773593 & $3.0 \odot 27 \odot 3$ \\
\hline _Ialterm_7 & 3.156523 & .0594586 & 53.09 & $\odot .00 \odot$ & 3.039985 & 3.273061 \\
\hline _Ialterm_8 & 3.490104 & .0640695 & 54.47 & $\odot . \odot \odot \odot$ & 3.364529 & 3.615679 \\
\hline _Ialterm_9 & 3.440343 & .0754123 & 45.62 & $\odot .00 \odot$ & 3. 292536 & 3.588149 \\
\hline Ialterm_10 & 3.101252 & .0938871 & 33.03 & $\odot . \odot \odot \odot$ & 2.917236 & 3.285269 \\
\hline Ialterm_11 & 2.918575 & .110643 & 26.38 & $\odot .0 \odot \odot$ & 2.701717 & 3.135433 \\
\hline cons & 119.4206 & .0543644 & 2196.67 & $\odot .000$ & 119.314 & 119.5271 \\
\hline
\end{tabular}




\section{CESifo Working Paper Series}

for full list see www.cesifo-group.org/wp

(address: Poschingerstr. 5, 81679 Munich, Germany, office@cesifo.de)

2124 Kurt R. Brekke, Luigi Siciliani and Odd Rune Straume, Competition and Waiting Times in Hospital Markets, October 2007

2125 Alexis Direr, Flexible Life Annuities, October 2007

2126 Johannes Becker and Clemens Fuest, Quality versus Quantity - The Composition Effect of Corporate Taxation on Foreign Direct Investment, October 2007

2127 Balázs Égert, Real Convergence, Price Level Convergence and Inflation Differentials in Europe, October 2007

2128 Marko Koethenbuerger, Revisiting the "Decentralization Theorem" - On the Role of Externalities, October 2007

2129 Axel Dreher, Silvia Marchesi and James Raymond Vreeland, The Politics of IMF Forecasts, October 2007

2130 Andreas Knabe and Ronnie Schöb, Subsidizing Extra Jobs: Promoting Employment by Taming the Unions, October 2007

2131 Michel Beine and Bertrand Candelon, Liberalization and Stock Market Co-Movement between Emerging Economies, October 2007

2132 Dieter M. Urban, FDI Technology Spillovers and Wages, October 2007

2133 Valentina Bosetti, Carlo Carraro, Emanuele Massetti and Massimo Tavoni, Optimal Energy Investment and R\&D Strategies to Stabilise Greenhouse Gas Atmospheric Concentrations, October 2007

2134 David-Jan Jansen and Jakob de Haan, The Importance of Being Vigilant: Has ECB Communication Influenced Euro Area Inflation Expectations?, October 2007

2135 Oliver Falck, Heavyweights - The Impact of Large Businesses on Productivity Growth, October 2007

2136 Xavier Freixas and Bruno M. Parigi, Banking Regulation and Prompt Corrective Action, November 2007

2137 Jan K. Brueckner, Partial Fiscal Decentralization, November 2007

2138 Silvia Console Battilana, Uncovered Power: External Agenda Setting, Sophisticated Voting, and Transnational Lobbying, November 2007

2139 Alan J. Auerbach, Michael P. Devereux and Helen Simpson, Taxing Corporate Income, November 2007 
2140 Lorenzo Cappellari, Paolo Ghinetti and Gilberto Turati, On Time and Money Donations, November 2007

2141 Roel Beetsma and Heikki Oksanen, Pension Systems, Ageing and the Stability and Growth Pact, November 2007

2142 Hikaru Ogawa and David E. Wildasin, Think Locally, Act Locally: Spillovers, Spillbacks, and Efficient Decentralized Policymaking, November 2007

2143 Alessandro Cigno, A Theoretical Analysis of the Effects of Legislation on Marriage, Fertility, Domestic Division of Labour, and the Education of Children, November 2007

2144 Kai A. Konrad, Mobile Tax Base as a Global Common, November 2007

2145 Ola Kvaløy and Trond E. Olsen, The Rise of Individual Performance Pay, November 2007

2146 Guglielmo Maria Caporale, Yannis Georgellis, Nicholas Tsitsianis and Ya Ping Yin, Income and Happiness across Europe: Do Reference Values Matter?, November 2007

2147 Dan Anderberg, Tax Credits, Income Support and Partnership Decisions, November 2007

2148 Andreas Irmen and Rainer Klump, Factor Substitution, Income Distribution, and Growth in a Generalized Neoclassical Model, November 2007

2149 Lorenz Blume, Jens Müller and Stefan Voigt, The Economic Effects of Direct Democracy - A First Global Assessment, November 2007

2150 Axel Dreher, Pierre-Guillaume Méon and Friedrich Schneider, The Devil is in the Shadow - Do Institutions Affect Income and Productivity or only Official Income and Official Productivity?, November 2007

2151 Valentina Bosetti, Carlo Carraro, Emanuele Massetti and Massimo Tavoni, International Energy R\&D Spillovers and the Economics of Greenhouse Gas Atmospheric Stabilization, November 2007

2152 Balázs Égert and Dubravko Mihaljek, Determinants of House Prices in Central and Eastern Europe, November 2007

2153 Christa Hainz and Hendrik Hakenes, The Politician and his Banker, November 2007

2154 Josef Falkinger, Distribution and Use of Knowledge under the "Laws of the Web", December 2007

2155 Thorvaldur Gylfason and Eduard Hochreiter, Growing Apart? A Tale of Two Republics: Estonia and Georgia, December 2007

2156 Morris A. Davis and François Ortalo-Magné, Household Expenditures, Wages, Rents, December 2007 
2157 Andreas Haufler and Christian Schulte, Merger Policy and Tax Competition, December 2007

2158 Marko Köthenbürger and Panu Poutvaara, Rent Taxation and its Intertemporal Welfare Effects in a Small Open Economy, December 2007

2159 Betsey Stevenson, Title IX and the Evolution of High School Sports, December 2007

2160 Stergios Skaperdas and Samarth Vaidya, Persuasion as a Contest, December 2007

2161 Morten Bennedsen and Christian Schultz, Arm's Length Provision of Public Services, December 2007

2162 Bas Jacobs, Optimal Redistributive Tax and Education Policies in General Equilibrium, December 2007

2163 Christian Jaag, Christian Keuschnigg and Mirela Keuschnigg, Pension Reform, Retirement and Life-Cycle Unemployment, December 2007

2164 Dieter M. Urban, Terms of Trade, Catch-up, and Home Market Effect: The Example of Japan, December 2007

2165 Marcelo Resende and Rodrigo M. Zeidan, Lionel Robbins: A Methodological Reappraisal, December 2007

2166 Samuel Bentolila, Juan J. Dolado and Juan F. Jimeno, Does Immigration Affect the Phillips Curve? Some Evidence for Spain, December 2007

2167 Rainald Borck, Federalism, Fertility and Growth, December 2007

2168 Erkki Koskela and Jan König, Strategic Outsourcing, Profit Sharing and Equilibrium Unemployment, December 2007

2169 Egil Matsen and Øystein Thøgersen, Habit Formation, Strategic Extremism and Debt Policy, December 2007

2170 Torben M. Andersen and Allan Sørensen, Product Market Integration and Income Taxation: Distortions and Gains from Trade, December 2007

2171 J. Atsu Amegashie, American Idol: Should it be a Singing Contest or a Popularity Contest?, December 2007

2172 Patricia Apps and Ray Rees, Household Models: An Historical Perspective, December 2007

2173 Ben Greiner, Axel Ockenfels and Peter Werner, The Dynamic Interplay of Inequality and Trust - An Experimental Study, December 2007

2174 Michael Melvin and Magali Valero, The Dark Side of International Cross-Listing: Effects on Rival Firms at Home, December 2007 
2175 Gebhard Flaig and Horst Rottmann, Labour Market Institutions and the Employment Intensity of Output Growth. An International Comparison, December 2007

2176 Alexander Chudik and M. Hashem Pesaran, Infinite Dimensional VARs and Factor Models, December 2007

2177 Christoph Moser and Axel Dreher, Do Markets Care about Central Bank Governor Changes? Evidence from Emerging Markets, December 2007

2178 Alessandra Sgobbi and Carlo Carraro, A Stochastic Multiple Players Multi-Issues Bargaining Model for the Piave River Basin, December 2007

2179 Christa Hainz, Creditor Passivity: The Effects of Bank Competition and Institutions on the Strategic Use of Bankruptcy Filings, December 2007

2180 Emilia Del Bono, Andrea Weber and Rudolf Winter-Ebmer, Clash of Career and Family: Fertility Decisions after Job Displacement, January 2008

2181 Harald Badinger and Peter Egger, Intra- and Inter-Industry Productivity Spillovers in OECD Manufacturing: A Spatial Econometric Perspective, January 2008

2182 María del Carmen Boado-Penas, Salvador Valdés-Prieto and Carlos Vidal-Meliá, the Actuarial Balance Sheet for Pay-As-You-Go Finance: Solvency Indicators for Spain and Sweden, January 2008

2183 Assar Lindbeck, Economic-Social Interaction in China, January 2008

2184 Pierre Dubois, Bruno Jullien and Thierry Magnac, Formal and Informal Risk Sharing in LDCs: Theory and Empirical Evidence, January 2008

2185 Roel M. W. J. Beetsma, Ward E. Romp and Siert J. Vos, Intergenerational Risk Sharing, Pensions and Endogenous Labor Supply in General Equilibrium, January 2008

2186 Lans Bovenberg and Coen Teulings, Rhineland Exit?, January 2008

2187 Wolfgang Leininger and Axel Ockenfels, The Penalty-Duel and Institutional Design: Is there a Neeskens-Effect?, January 2008

2188 Sándor Csengődi and Dieter M. Urban, Foreign Takeovers and Wage Dispersion in Hungary, January 2008

2189 Joerg Baten and Andreas Böhm, Trends of Children's Height and Parental Unemployment: A Large-Scale Anthropometric Study on Eastern Germany, 1994 2006, January 2008 